\title{
ASSOCIATION BETWEEN SOCIAL ACKNOWLEDGMENT AND TRAUMA DISCLOSURE
}

\author{
Evaldas Kazlauskas, Paulina Želvienè, Jonas Eimontas, Goda Gegieckaitė \\ Vilnius University, Department of Clinical and Organizational Psychology, Lithuania
}

Key words: disclosure, trauma, PTSD, social acknowledgment.

\begin{abstract}
Summary
Trauma disclosure can facilitate trauma recovery. However, survivors might be reluctant to talk about their traumatic experiences if they perceive that their experiences are not acknowledged. We aimed to explore how social acknowledgment is associated with trauma disclosure in a sample of Lithuanian trauma survivors. In total 189 survivors exposed to various traumatic experiences participated in the study. Regression analysis revealed that trauma survivors were more willing to disclose their traumatic experiences when they perceived more social recognition and less disapproval from others. We conclude that our study indicates the importance of social acknowledgment for trauma disclosure among trauma survivors.
\end{abstract}

\section{Introduction}

Trauma disclosure after traumatic events can facilitate trauma recovery. There is a growing body of evidence that trauma disclosure can have a significant positive effect on the health and well-being of trauma survivors. Several metaanalysis of trauma disclosure revealed significant positive effects on physical and psychological health outcomes $(1,2)$. Research also indicated that previous disclosure of traumatic events was associated with increased emotional coping, positive life changes after traumatic experience and posttraumatic growth (3), and less posttraumatic stress disorder symptoms $(4,5)$. Research on trauma disclosure was largely influenced by the Pennebaker paradigm which proposed emotional writing as a method of coping with trauma (6). Even though the Pennebaker paradigm can be helpful for trauma survivors, there is increasing awareness that survivors are very often avoiding disclosure of trauma. This indicates that the writing paradigm has its limits, because in real-life situations trauma disclosure is always related with an interpersonal context in which survivors disclose trauma to others.

A recent theoretical formulation by Maercker and Horn included trauma disclosure in a socio-interpersonal traumatic stress framework as one of the factors contributing to recovery after trauma (7). Moreover, they proposed that trauma disclosure is related to social acknowledgment of survivors (7). Social acknowledgment as a victim or survivor was defined by Maercker and Müller as survivors' experience of society's reactions towards the survivor and perceived acknowledgment of the survivor's current difficult situation (8). The proposed social acknowledgment phenomenon is conceptually different from social support because of the inclusion of a broader social context (8). Furthermore, the survivor's adaptation to traumatic stressors is affected not only by family or friends, but also by societal reactions and public opinion about the survivors of traumatic events. These reactions from society can vary a lot, and can range from sympathy and support to negative reactions. These perceived societal reactions therefore can facilitate or hinder trauma disclosure. While trauma disclosure is important for trauma recovery, survivors might be reluctant to talk with others about their traumatic experiences if they perceive that family members, co-workers or the community react negatively to their experiences, ignore, reject or even blame the victim. On the other hand, recognition and sympathy from others could facilitate the survivors need to disclose trauma and consequently may contribute to trauma recovery. Social acknowledgment research was facilitated by the introduction of the multidimensional Social Acknowledgment Questionnaire (SAQ) by Maercker and Müller in 2004 (8). Since then several studies showed that social acknowledgment can be a significant protective factor following trauma exposure $(9,10)$. Studies also indicated that trauma disclosure might be associated with social acknowledgment $(4,9)$. However, there are no studies exploring how different dimensions of social acknowledgment are associated with trauma disclosure.

Aims of the study - we aimed to explore how social acknowledgment is associated with trauma disclosure in a 
Lithuanian community sample of various traumatic events survivors. We hypothesized that trauma disclosure would be associated with PTSD symptoms and social acknowledgment would be associated with trauma disclosure.

\section{Method}

Participants and procedures. The study was approved by the Institutional Psychological Research Ethics Committee. Participants were recruited at various locations in Lithuania in community settings: home, workplace or public spaces. In total $78.7 \%$ of people invited agreed to participate in the study. Inclusion criteria for this study were: 1 ) $\geq 18$ years old; 2) exposure to at least one lifetime traumatic experience. Participants were asked to fill in self-report questionnaires with the assistance of trained interviewers. Prior to assessments each participant was given an oral and written briefing about the study and written informed consent was obtained.

In total 189 participants, 73 men (38.6\%) and 116 women (61.4\%) participated in this study. The age of the participants ranged from 18 to 78 years, the mean age was $34.44(S D=$ 14.40). The majority of participants were from urban areas $(80.3 \%), 13.8 \%$ were from rural areas, and $5.9 \%$ of participants were living abroad. Almost half of the participants $(43.3 \%)$ had university education.

Measures. We used the International Trauma Questionnaire (ITQ) $(11,12)$ version 1.5 for posttraumatic stress disorder (PTSD) symptom assessments. This self-report measure is based on the World Health Organization (WHO) ICD-11 working group for disorders specifically associated with stress proposals for PTSD diagnosis (13), and is currently in development with ongoing validation studies in several languages worldwide (12). In this study only the first part of ITQ comprising of 15 items measuring symptoms of PTSD was used. Participants were asked to identify the traumatic or stressful experience that troubles them the most and then rate on a Likert scale ranging from $0(=$ Not at all $)$ to $5(=$ Extremely) how much they have been bothered by each of the symptom, related to that event, during the past month. Three core PTSD symptoms were measured: Re-experiencing (3 items), Avoidance ( 2 items) and Sense of threat (2 items). If any of the items in the symptom cluster was rated $\geq 2$, then the person was considered to be experiencing that symptom. A PTSD criterion was considered met if all three symptoms were positive. Double back translation was used for the ITQ translation to the Lithuanian language. Measure is still in development, but other studies using ITQ showed good composite reliability for all subscales $(\alpha=.72-.86)$ (12). Reliability of the ITQ measured with Cronbach's alpha was good in our sample $(\alpha=.82)$.
The Life Events Checklist (LEC) (14) was used for screening of lifetime trauma exposure. The LEC consists of 17 potentially traumatic events like physical or sexual abuse, combat, assault with weapon, exposure to violent death and others. Participants that reported to have experienced or witnessed traumatic events, were considered to be exposed to traumatic event. Studies of the psychometric properties of the LEC showed good stability and convergence with other traumatic life events measures (15).

The Disclosure of Trauma Questionnaire (DTQ) (16) was used to measure participants' trauma disclosure. In this study the brief version of the DTQ comprising of 12 items was used. Items measured willingness to disclose. For the calculation of the DTQ score some items were reversed. Higher score on the DTQ-12 indicated lower willingness to disclose. Each item of the DTQ-12 is rated on a Likert scale ranging from 0 (= Not at all) to 5 (= Completely) by the trauma survivor. In our study participants were asked to answer DTQ questions in relation to the most troubling experience referred in ITQ. The DTQ was translated to Lithuanian language using back translation and consulting with the authors of the DTQ. Cronbach's $\alpha$ for original scale was from. $82-.88$ (16). In our study Cronbach's $\alpha$ for the DTQ was .73.

The Social Acknowledgment Questionnaire (SAQ) (8) was used to measure the perceived level of acknowledgment of person being a victim or survivor from family, friends, acquaintances, and authorities. The SAQ comprise of 16 items that are rated on a Likert scale ranging from $0(=\mathrm{Not}$ at all) to 5 (=Completely). The SAQ includes three subscales: recognition as victim (6 items), general disapproval (5 items), and family or friends' disapproval (5 items). The SAQ recognition as victim subscale measures perceived positive support from environment. The SAQ general disapproval subscale measures perceived rejection by extended social environment like society in general, institutions, community. The SAQ family and friends' disapproval subscale measures perceived negative reactions from close social environment like family, and friends. In our study participants were asked to answer the SAQ questions in relation to the most troubling experience referred in the ITQ. Cronbach's $\alpha$ for original scale was from $.79-.86(8)$. In this study psychometric properties of the SAQ were satisfactory with Cronbach's $\alpha$ $=.73$ for the total SAQ scale, and Cronbach's $\alpha=.68$ for general disapproval subscale, .75 for recognition subscale, and .59 for subscale of family and friends' disapproval. The SAQ was translated to Lithuanian language using the back translation procedure.

Data analysis. Data analyses were conducted with IBM SPSS Statistics version 23. 


\section{Results}

Trauma exposure and PTSD symptoms. Participants experienced $4.77(S D=3.19)$ lifetime traumatic events on average, ranging from one to 17 events. The most common traumatic events were sudden, unexpected death of a close one $(n=125,66.8 \%)$, transportation accident ( $n=$ $88,47.1 \%)$, physical abuse in childhood ( $n=78,41.9 \%)$, physical abuse in adulthood $(n=63,33.9 \%)$, severe human suffering $(n=60,31.9 \%)$. About a quarter $(n=42,22.2 \%)$ of participants experienced traumatic event less than a year ago, with another quarter $(n=52,27.5 \%)$ reported they experienced the most distressing event one to five years ago, $14.3 \%(n=27)$ experienced traumatic event from 5 to 10 years ago and remaining participants $(n=36,24.4 \%)$ experienced traumatic event more than ten years ago. There was no significant gender $(t(187)=0.08, p=.940)$ or age $(r=-.08, p=.275)$ effects on number of experienced traumatic events. However, there were gender effects on types of experienced traumas. Men more often than women experienced exposure to toxic substance $\left(\chi^{2}(1, n=189)=4.67\right.$, $\mathrm{p}=.031)$; transportation accident $\left(\chi^{2}(1, n=189)=6.81\right.$, $\mathrm{p}=.009)$; physical abuse in adulthood $\left(\chi^{2}(1, n=189)=\right.$ $5.76, \mathrm{p}=.016)$ and assault with a weapon $\left(\chi^{2}(1, n=189)=\right.$ $7.14, \mathrm{p}=.005)$. Women more often than men experienced unwanted or uncomfortable sexual experiences $\left(\chi^{2}(1, n=\right.$ $189)=8.39, \mathrm{p}=.005)$; severe human suffering $\left(\chi^{2}(1, n=\right.$
$189)=6.43, \mathrm{p}=.011)$ and sudden violent death $\left(\chi^{2}(1, n=\right.$ $189)=10.11, \mathrm{p}=.001)$.

In our study $14.8 \%(n=28)$ of participants met full criteria for PTSD. Almost the same percentage $(14.3 \%, n=27)$ had subclinical levels of PTSD, with two core PTSD symptoms at clinical level. We found significant gender effects on PTSD prevalence in our sample. Women had higher rates of PTSD and subclinical PTSD combined $(37.9 \%, n=44)$ in comparison to men $(15.1 \%, n=11)\left(\chi^{2}(1, n=189)=11.35\right.$, $\mathrm{p}=.001)$. There were no significant associations of PTSD symptoms with age $(r=-.10, p=.195)$ in our sample.

Gender and age effects on disclosure and social acknowledgment. We found significant age effect on the SAQ subscale general disapproval $(r=.16, p=.039)$, increased age was associated with higher general disapproval. There were no statistically significant correlations between age and the DTQ score $(r=.06, p>.05)$.

We found significant gender effects on trauma disclosure. Women had lower scores $(M=12.77, S D=4.61)$ of the DTQ than men $\operatorname{did}(M=14.44, S D=4.33)(t(177)=$ $-2.41 ; p=.017)$. There were no significant gender effects on perceived social acknowledgment from family or friends $(t$ $(176)=-0.12 ; p=.906)$ and recognition $(t(163)=-0.83 ; p$ $=.406)$, but women $(M=4.75, S D=3.11)$ had higher scores of perceived general disapproval in comparison to men $(M$ $=3.70, S D=3.00)(t(178)=-2.21 ; p=.028)$.

Associations between trauma

Table 1. Means, Standard Deviations and Correlations between PTSD, Trauma Disclosure, and Social Acknowledgment

Note. $S A Q=$ Social Acknowledgment Questionnaire

$* p<.05, * * p<.01$

\begin{tabular}{|l|c|c|c|c|c|c|c|c|}
\hline Measure & $\boldsymbol{M}$ & $\boldsymbol{S D}$ & $\mathbf{1}$ & $\mathbf{2}$ & $\mathbf{3}$ & $\mathbf{4}$ & $\mathbf{4 . 1}$ & $\mathbf{4 . 2}$ \\
\hline 1. PTSD symptoms & 0.96 & 1.10 & & & & & & \\
\hline 2. Lifetime trauma exposure & 4.77 & 3.19 & $.18^{*}$ & & & & & \\
\hline 3. Trauma disclosure & 26.95 & 9.65 & $.36^{* *}$ & .08 & & & & \\
\hline 4. SAQ total & 27.23 & 7.37 & -.15 & -.13 & $-.30^{* *}$ & & & \\
\hline 4.1. SAQ General disapproval & 4.36 & 3.10 & $.34^{* *}$ & .08 & $.38^{* *}$ & $-.65^{* *}$ & & \\
\hline 4.2. SAQ Family/friends' disapproval & 5.14 & 2.97 & $.25^{* *}$ & $.20^{* *}$ & $.19^{*}$ & $-.80^{* *}$ & $.48^{* *}$ & \\
\hline 4.3. SAQ Recognition & 6.52 & 4.09 & .16 & -.08 & .12 & $.73^{* *}$ & -.08 & $-.36^{* *}$ \\
\hline
\end{tabular}

Table 2. Regression Analysis Predicting Trauma Disclosure

Note. $S A Q=$ Social Acknowledgment Questionnaire

${ }^{a} 1=$ men, $2=$ women $; * * p<.001, * * p<.01, * p<.05$

\begin{tabular}{|l|c|c|c|c|c|}
\hline Trauma disclosure predictors & $\boldsymbol{B}$ & $\boldsymbol{S . E}$. & $\boldsymbol{\beta}$ & $\boldsymbol{F}$ & $\boldsymbol{R}^{\mathbf{2}}$ \\
\hline SAQ General disapproval & 0.90 & 0.27 & $.29^{* * *}$ & $10.31^{* * *}$ & .26 \\
\hline SAQ Family/ friends' disapproval & -0.35 & 0.30 & -.10 & & \\
\hline SAQ Recognition & -0.48 & 0.19 & $-.20^{*}$ & & \\
\hline PTSD symptoms & 3.19 & 0.72 & $.36^{* * *}$ & & \\
\hline Gender ${ }^{\text {a }}$ & -0.02 & 1.50 & -.00 & & \\
\hline Constant & 24.82 & 3.15 & & & \\
\hline
\end{tabular}

disclosure and social acknowled-

gment. Statistically significant correlations were found between PTSD and the DTQ score $(r=$ $.36, p<.01)$. Correlation between PTSD symptoms and the total SAQ score was non-significant $(r=-.15, p>.05)$. Analysis of correlations between PTSD and the SAQ subscales revealed that PTSD symptoms were statistically significantly correlated with the two SAQ subscales: 1) general disapproval, and 2) family and friends' disapproval (See Table 1).

There was a statistically significant correlation between the SAQ total score and the DTQ score. The DTQ score was significantly associated with the SAQ general disapproval and family and friends' disapproval (See Table 1). 
There was a significant association between trauma exposure measured by the total number of lifetime traumatic events and SAQ subscale of family and friends' disapproval (See Table 1). There were no other significant associations between lifetime trauma exposure and the SAQ subscales and the DTQ score. Based on the finding that lifetime trauma exposure was not associated with trauma disclosure, lifetime trauma exposure was not included in further analysis.

Regression analysis was carried out with all the SAQ subscales as predictors of trauma disclosure (See Table 2). PTSD symptoms and gender was included in regression analysis, as previous analysis revealed significant gender effects on trauma disclosure, and PTSD symptoms were significantly associated with trauma disclosure. Regression showed no violations of regression analysis assumptions. The collinearity between variables was from low to medium $(r=.03-.49), \mathrm{VIF}=1.11-1.57$; Cook's distance $<0.10$ and residual plot showed normal distribution. Regression analysis showed that the DTQ score was significantly predicted by the SAQ subscales general disapproval and recognition and PTSD symptoms. The regression model explained $26 \%$ of the variance (See Table 2).

\section{Discussion}

Results of this study support previous findings and contribute new knowledge on how trauma disclosure is associated with the social context of trauma survivors. In line with the previous research we found that trauma disclosure was associated with PTSD symptoms $(2,17)$. Findings of our study also indicated that trauma disclosure might be predicted by social acknowledgment. Several studies indicated possible associations between trauma disclosure and social acknowledgment $(4,9)$, however these associations were not analyzed in detail previously.

Our study's findings suggest that trauma disclosure can be predicted by perceived social acknowledgment even when controlling for PTSD symptoms and gender. We found that higher general disapproval significantly predicted lower willingness to disclose the traumatic experience and higher recognition predicted higher willingness to disclose. Family and friends' disapproval did not significantly predict trauma disclosure. These findings suggest an interesting pattern where the perceived recognition and reactions from a broader social context might be more important for trauma disclosure than a perceived reactions and acknowledgment from a closer circle of family and friends of trauma survivors. Our results are similar to findings of a previous study that reported significant association between social acknowledgment, disclosure, and PTSD symptoms (8). Trauma survivors might be sensitive to the community reactions towards survivors, and perceived negative reactions or disapproval from a community could result in avoidance of trauma disclosure based on our findings.

Our data analysis revealed significant gender effects on trauma disclosure and social acknowledgment. Men were more reluctant to disclose traumatic events. These results are in line with the previous studies that revealed gender differences in posttraumatic stress reactions (18) and disclosure of trauma (19). We also found gender differences in types of experienced traumatic events, which might be closely related to gender differences in trauma disclosure and social acknowledgment. Our study results suggest there might be gender related differences in social acknowledgment following traumatic events, and gender effects on trauma disclosure, which should be explored further in future studies.

There is a growing awareness of the need for cultural sensitivity in the field of traumatic stress research and clinical practice (20). The two social context related factors of social acknowledgment and trauma disclosure in this study are culture specific. A recent review reported $70-75 \%$ prevalence of traumatic events in the general population in Lithuania (21) similar to $68 \%$ prevalence of traumatic experiences in other European countries (22). However, several crosscultural studies revealed high prevalence of interpersonal violence in Lithuania including physical abuse in childhood (26.0\%) (23) and domestic violence towards mother (16.5\%) (24), and high levels of PTSD (30\%) among second-generation survivors of political violence (25), indicating that Lithuanian population might have high rates of survivors of interpersonal trauma.

Taking into account the specific social context with major social changes in Lithuania over the last several decades $(21,26)$, and the long history of political oppression with a specific communication in families marked with a tendency to keep secrets about traumatic experiences (27), Lithuanians might be more avoidant to disclose traumatic experiences. Moreover, the recent Lithuanian National Health Care data analysis revealed extremely low rates of PTSD diagnosis in the health care (28), indicating the lack of recognition of stress-related disorders in the country. The lack of recognition of survivors could contribute to the results that the role of social acknowledgment is very important for disclosing of trauma in Lithuania. Specificity of our studies sample indicates the need for the cross-cultural studies of trauma related disclosure reactions and associations with social acknowledgment across different countries and cultures.

Several limitations of our study should be considered. Our study was cross-sectional and correlational analysis has its limits. Further studies and preferably longitudinal ones are needed to analyze the role of social acknowledgment on 
trauma disclosure. We included survivors of various traumas. However, there might be significant differences in acknowledgment of trauma survivors in society. Some traumas, such as, sexual abuse or childhood trauma might be more stigmatizing and more difficult to disclose (17). Attitudes towards survivors of these traumas in society might be more negative, resulting in lower perceived social acknowledgment and reluctance to talk. Our study sampling of inviting participants to participate in the study in the community settings might have created some bias in disclosure results, as people who agreed to participate might have been more open to disclosure than people who did not agree to participate. The sample size was rather small and generalization of our findings to other samples should be made with caution. Despite these limitations preliminary findings of our study indicate the importance of social acknowledgment of survivors on trauma disclosure, and opens up new avenues for further research in this direction.

\section{Conclusions}

Our study indicates the importance of social acknowledgment on trauma disclosure among trauma survivors. We found that trauma survivors were more willing to disclose their traumatic experiences when they perceived more social recognition and less disapproval from others. Our study findings inform health care professionals, policy makers, and other stakeholders about the importance of social factors, and especially perceived social acknowledgment on trauma disclosure, which might be closely related to help-seeking behaviors, and consequently recovery of trauma survivors.

\section{Acknowledgments}

This research was funded by a grant (No. MIP-006/2015) from the Research Council of Lithuania.

\section{References}

1. Frattaroli J. Experimental disclosure and its moderators: a metaanalysis. Psychol Bull 2006;132(6):823-65. https://doi.org/10.1037/0033-2909.132.6.823

2. Frisina PG, Borod JC, Lepore SJ. A meta-analysis of the effects of written emotional disclosure on the health outcomes of clinical populations. J Nerv Ment Dis 2004;192(9):629-34. https://doi.org/10.1097/01.nmd.0000138317.30764.63

3. Hassija CM, Turchik JA. An examination of disclosure, mental health treatment use, and posttraumatic growth among college women who experienced sexual victimization. J Loss Trauma 2016;21(2):124-36. https://doi.org/10.1080/15325024.2015.1011976

4. Mueller J, Moergeli H, Maercker A. Disclosure and social acknowledgement as predictors of recovery from posttraumatic stress: a longitudinal study in crime victims. Canadian Journal of Psychiatry 2008; 53:160-8.

https://doi.org/10.1177/070674370805300306

5. Ullman SE, Starzynski LL, Long SM, Mason GE, Long LM. Exploring the relationships of women's sexual assault disclosure, social reactions, and problem drinking. J Interpers Violence 2008;23(9):1235-57.

https://doi.org/10.1177/0886260508314298

6. Pennebaker JW, Kiecolt-Glaser JK, Glaser R. Disclosure of traumas and immune function: health implications for psychotherapy. J Consult Clin Psychol 1988;56(2):239.

https://doi.org/10.1037/0022-006X.56.2.239

7. Maercker A, Horn AB. A socio-interpersonal perspective on PTSD: The case for environments and interpersonal processes. Clin Psychol Psychother 2013;20(6):465-81. https://doi.org/10.1002/cpp.1805

8. Maercker A, Müller J. Social acknowledgment as a victim or survivor: A scale to measure a recovery factor of PTSD. J Trauma Stress 2004;17(4):345-51. https://doi.org/10.1023/B:JOTS.0000038484.15488.3d

9. Maercker A, Povilonyte M, Lianova R, Pöhlmann K. Is acknowledgment of trauma a protective factor?: The sample case of refugees from chechnya. Eur Psychol 2009;14(3):249-54. https://doi.org/10.1027/1016-9040.14.3.249

10. Wagner B, Keller V, Knaevelsrud C, Maercker A. Social acknowledgement as a predictor of post-traumatic stress and complicated grief after witnessing assisted suicide. Int J Soc Psychiatry 2012;58(4):381-5. https://doi.org/10.1177/0020764011400791

11. Cloitre M, Roberts N, Bisson JI, Brewin CR. ICD-11 Trauma Questionnaire. Self-Report Research Version 1.5.1. 2016.

12. Karatzias T, Shevlin M, Fyvie C, Hyland P, Efthymiadou E, Wilson D. et al. An initial psychometric assessment of an ICD11 based measure of PTSD and complex PTSD (ICD-TQ): Evidence of construct validity. J Anxiety Disord 2016;44:73-9. https://doi.org/10.1016/j.janxdis.2016.10.009

13. Maercker A, Brewin CR, Bryant R, Cloitre M, Van Ommeren M, Jones LM. et al. Diagnosis and classification of disorders specifically associated with stress: Proposals for ICD-11. World Psychiatry 2013;12(3):198-206.

https://doi.org/10.1002/wps.20057

14. Weathers FW, Blake DD, Schnurr PP, Kaloupek DG, Marx BP, Keane TM. The life events checklist for DSM-5 (LEC-5). Instrum available from Natl Cent PTSD www.ptsd.va.gov. 2013.

15. Gray MJ, Litz BT, Hsu JL, Lombardo TW. Psychometric properties of the life events checklist. Assessment 2004;11(4):330-41. https://doi.org/10.1177/1073191104269954

16. Müller J, Beauducel A, Raschka O, Maercker A. Kommunikationsverhalten nach politischer Haft in der DDR - Entwicklung eines Fragebogens zum Offenlegen der Traumaerfahrungen. Zeitschrift für Polit Psychol 2000;8(2):413-27. 
17. Bedard-Gilligan M, Jaeger J, Echiverri-Cohen A, Zoellner LA. Individual differences in trauma disclosure. J Behav Ther Exp Psychiatry 2012;43(2):716-23. https://doi.org/10.1016/j.jbtep.2011.10.005

18. Kilpatrick DG, Resnick HS, Milanak ME, Miller MW, Keyes KM, Friedman MJ. National estimates of exposure to traumatic events and PTSD prevalence using DSM-IV and DSM-5 criteria. J Trauma Stress 2013 Oct;26(5):537-47. https://doi.org/10.1002/jts.21848

19. Pielmaier L, Maercker A. Psychological adaptation to life-threatening injury in dyads: the role of dysfunctional disclosure of trauma. Eur J Psychotraumatol 2011;2:1-12. https://doi.org/10.3402/ejpt.v2i0.8749

20. Schnyder U, Bryant RA, Ehlers A, Foa EB, Hasan A, Mwiti G. et al. Culture-sensitive psychotraumatology. Eur J Psychotraumatol 2016. https://doi.org/10.3402/ejpt.v7.31179

21. Kazlauskas E, Zelviene P. Trauma research in the Baltic countries: From political oppression to recovery. Eur J Psychotraumatol 2016; 7 https://doi.org/10.3402/ejpt.v7.29295

22. Darves-Bornoz J-M, Jordi A, de Girolamo G, de Graaf R, Haro J-M, Kovess-Masfety V. et al. Main traumatic events in Europe: PTSD in the European study of the epidemiology of mental disorders survey. J Trauma Stress 2008;21(5):455-62. https://doi.org/10.1002/jts.20357

23. Sebre S, Sprugevica I, Novotni A, Bonevski D, Pakalniskiene V, Popescu D. et al. Cross-cultural comparisons of child-reported emotional and physical abuse: Rates, risk factors and psychosocial symptoms. Child Abus Negl 2004;28(1):113-27. https://doi.org/10.1016/j.chiabu.2003.06.004

24. Bellis MA, Hughes K, Leckenby N, Jones L, Baban A, Kachaeva M. Adverse childhood experiences and associations with health-harming behaviours in young adults : surveys in eight eastern European countries 2014;(92):641-55.

25. Kazlauskas E, Gailiene D, Vaskeliene I, Skeryte-Kazlauskiene M. Intergenerational transmission of resilience? Sense of coherence is associated between Lithuanian survivors of political violence and their adult offspring. Front Psychol 2017;8:1-8. https://doi.org/10.3389/fpsyg.2017.01677

26. Kazlauskas E, Zelviene P. Association between posttraumatic stress and acceptance of social changes: Findings from a general population study and proposal of a new concept. Int J Soc Psychiatry 2017. https://doi.org/10.1177/0020764016687788

27. Vaskeliene I. Long-term psychological effects of political repression in Lithuania to second generation (Summary of doctoral dissertation). Vilnius: Vilnius University, 2012.

28. Kazlauskas E, Zelviene P, Eimontas J. "No posttraumatic stress disorder in Lithuania": National health care fails to identify PTSD. J Trauma Stress 2017;30(1):99-102.

https://doi.org/10.1002/jts.22152

\section{SĄSAJOS TARP SOCIALINIO PRIPAŽINIMO IR ATSISKLEIDIMO PO TRAUMOS}

E. Kazlauskas, P. Želvienė, J. Eimontas, G. Gegieckaitė

Raktažodžiai: trauma, PTSS, socialinis pripažinimas, atsiskleidimas.

Santrauka

Atsiskleidimas apie trauminę patirtị gali padèti įveikti su traumuojančia patirtimi susijusius psichologinius sunkumus. Tyrimais patvirtinta, kad atsiskleidimas po traumos yra vienas reikšmingiausių veiksnių, prisidedančių prie psichologinių traumų ịveikos. Žmonès, patyrę traumuojančius ịvykius, dažnai vengia atsiskleisti apie šias patirtis, ypač jei galvoja, kad jos yra nepripažįstamos aplinkinių asmenų. Jei asmenys jaučia kitų pripažinimą ir palaikymą, tai gali paskatinti atsiskleidimą ir padèti ịveikti sunkumus, susijusius su traumine patirtimi. Šio tyrimo tikslas buvo ịvertinti, kaip socialinis pripažinimas yra susijęs su atsiskleidimu po traumos. Iš viso tyrime dalyvavo 189 ịvairias traumas patyrę asmenys, iš kurių buvo 116 moteru (61,4 proc.) ir 73 vyrai (38,6 proc.). Tyrimo dalyvių amžius buvo nuo 18 iki 78 metų, amžiaus vidurkis 34,44 m. $(\mathrm{SD}=14,40)$. Tyrimo dalyvių trauminei patirčiai įvertinti buvo naudotas Gyvenimo įvykių sąrašas (LEC), potrauminio streso reakcijoms įvertinti naudotas Tarptautinis traumos klausimynas (ITQ). Psichosocialiniai su trauma susiję veiksniai buvo ivertinti naudojant Atsiskleidimo po traumos klausimyną (DTQ) bei Socialinio pripažinimo klausimyną (SAQ). Tyrimo dalyviai buvo patyrę vidutiniškai 4,7 trauminio įvykio per gyvenimą. 14,8 proc. $(\mathrm{n}=28)$ tyrimo dalyvių turejo klinikinio lygio potrauminio streso sutrikimo simptomų. Nustatytos statistiškai reikšmingos sąsajos tarp potrauminio streso sutrikimo simptomų ir trauminès patirties, traumos atsiskleidimo ir šeimos narių, draugų ar kitų asmenų neigiamų reakcijų. Regresinè analizè atskleidè, kad labiau savo traumines patirtis buvo linkę atskleisti tie tyrimo dalyviai, kurie iš kitų jaute daugiau palaikymo ir mažiau nepritarimo. Tyrimo rezultatai patvirtina socialinio pripažinimo svarbą atsiskleisti po traumuojančių patirčių. Adresas susirašinèti: evaldas.kazlauskas@ffsf.vu.lt

Gauta 2017-12-01 